\title{
PERANCANGAN MEDIA PEMBELAJARAN BERBASIS AUDIO VISUAL UNTUK MATA KULIAH TIPOGRAFI PADA PROGRAM STUDI DESAIN KOMUNIKASI VISUAL, UNIVERSITAS DIAN NUSWANTORO
}

\author{
Puri Sulistiyawati ${ }^{1}$, Dwi Puji Prabowo ${ }^{2}$, Dimas Irawan Ihya' Ulumuddin ${ }^{3}$ \\ 1,2,3 Desain Komunikasi Visual, Fakultas Ilmu Komputer, Universitas Dian Nuswantoro Semarang \\ puri.sulistiya@gmail.com ${ }^{1}$,prabowo.dinus@gmail.com², dimas.dkv@gmail.com ${ }^{3}$
}

\begin{abstract}
Abstrak
Tipografi merupakan salah satu mata kuliah pada bidang desain komunikasi visual yang mengutamakan aspek visual. Namun berdasarkan hasil observasi diketahui bahwa media pembelajaran yang selama ini digunakan kurang efektif karena kurangnya pemanfaatan teknologi informasi, sehingga mahasiswa kurang maksimal dalam memahami materi kuliah yang disampaikan oleh pengajar. Perkembangan teknologi informasi saat ini banyak memberikan dampak positif bagi kemajuan bidang pendidikan diantaranya dapat digunakan untuk mendukung media dalam proses pembelajaran. Tujuan penelitian ini adalah merancang media pembelajaran untuk mata kuliah tipografi dengan memanfaatkan teknologi informasi yaitu media audio visual. Metode yang digunakan dalam penelitian ini adalah Research and Development dengan pendekatan model ADDIE (Analysis, Design, Development, Implementation, Evaluation). Dengan diciptakannya media pembelajaran audio visual ini diharapkan proses pembelajaran mata kuliah Tipografi dapat lebih efektif dan materi kuliah lebih mudah dipahami oleh mahasiswa.
\end{abstract}

Kata Kunci : audio visual, media pembelajaran, tipografi

\begin{abstract}
Typography is one of the subjects in the field of visual communication design that prioritizes the visual aspect. However, based on the observation note that the media has been used less effective because the lack of use information technology, so students can't understand the course material that explained by lecturers. Today, the development of information technology is being positive impact for the advancement of education which can be used to support the media in the learning process. The purpose of this research is to design learning media for the course of typography by utilizing information technology, called audio-visual media. The method that used in this research is Research and Development with ADDIE model (Analysis, Design, Development, Implementation, Evaluation). With the creation of audio-visual learning media is expected Typography learning courses can be more effective and the course material more easily understood by students.
\end{abstract}

Keywords : audio visual, instructional media, typography 


\section{PENDAHULUAN}

Perkembangan teknologi informasi yang kian pesat memberikan berbagai kemudahan dalam kehidupan manusia. Hal ini mendorong terciptanya inovasi dalam segala bidang, diantaranya adalah bidang pendidikan. Dalam bidang pendidikan, teknologi informasi dimanfaatkan sebagai media pembelajaran untuk mendukung proses kegiatan belajar yang lebih efektif, karena banyak aplikasi komputer yang diciptakan untuk memudahkan proses pembelajaran. Menurut Rahil Mahyuddin dalam Nini Subini pembelajaran adalah perubahan tingkah laku dengan melibatkan ketrampilan kognitif yang meliputi penguasaan ilmu dan perkembangan kemahiran intelektual [1]. Dalam sebuah proses pembelajaran ada beberapa faktor yang dapat menentukan kualitas pendidikan, salah satunya adalah strategi penyampaian materi oleh pengajar. Strategi ini tentunya akan berpengaruh pada motivasi belajar dan meningkatkan pemahaman mahasiswa terhadap materi yang disampaikan.

Bahan ajar sebagai salah satu sarana penunjang dapat dikembangan melalui beberapa cara, salah satunya adalah mengoptimalisasi media yang digunakan dalam penyampaian bahan ajar atau yang disebut dengan media pembelajaran. Namun saat ini sistem pengajaran yang digunakan masih banyak yang bersifat monoton. Kurangnya media teknologi komunikasi yang menarik dalam penyampaian materi membuat mahasiswa cepat jenuh. Seperti halnya dalam pembelajaran mata kuliah Tipografi di Universitas Dian Nuswantoro. Mata kuliah ini merupakan salah satu bagian dalam kurikulum Program Studi Desain Komunikasi Visual. Menurut Adi Kusrianto, tipografi merupakan suatu seni dalam huruf yang meliputi pemilihan jenis huruf, menentukan ukuran huruf yang tepat, yang mana sebuah teks dapat diputus dengan jarak spasi tertentu, dan bagaimana sebuah teks dapat dibaca dengan mudah oleh pembaca [2]. Tujuan mata kuliah tipografi dalam desain adalah memberikan pemahaman tentang huruf baik untuk disiplin ilmu maupun seni tipografi, mulai dari sejarah perkembangan huruf, anatomi huruf, merancang huruf, eksplorasi huruf, pemilihan dan penataan huruf maupun penerapan huruf dalam sebuah media untuk menyampaikan pesan maupun mengungkapkan ide atau informasi dalam bentuk visual.

Dari hasil observasi yang dilakukan terdapat dilematisasi para pengajar dalam mengoptimalkan proses pembelajaran untuk mencapai tujuan yang diharapkan. Berbagai upayapun telah banyak dilakukan dengan menggunakan metode pembelajaran yang beraneka ragam. Meskipun begitu, kerapkali dalam tahap evaluasi proses pembelajaran muncul ketidakpuasan para pengajar dengan hasil yang kurang maksimal karena mahasiswa tidak dapat memahami materi secara utuh, sehingga pengaplikasian materi kedalam prakteknya sering tidak sesuai. Dengan begitu, untuk mengatasi permasalahan tersebut dibutuhkan pengembangan media pembelajaran yang berguna untuk menunjang keberhasilan mahasiswa dalam mencapai kompetensi yang diajarkan, serta dapat menumbuhkan antusias dan motivasi belajar mahasiswa. Media audio visual merupakan salah satu sarana pembelajaran yang berbasis teknologi informasi dan komunikasi, yang mana dapat digunakan sebagai alternatif untuk mendukung proses pembelajaran yang lebih optimal [3]. Penggunaan media audio visual sebagai media pembelajaran sangat tepat diterapkan dalam mata kuliah 
Tipografi, karena terdapat efek audio visual yang sesuai dengan mata kuliah Tipografi yang menekankan aspek visual, sehingga mahasiswa lebih mudah dalam proses belajar.

\section{TINJAUAN PUSTAKA}

\subsection{Media Pembelajaran}

Media adalah sebuah komponen sumber belajar atau wahana fisik yang mengandung materi instruksional di lingkungan siswa yang dapat memotivasi para siswa dalam belajar [4]. Dalam proses pengajaran, media pembelajaran memiliki beberapa manfaat diantaranya, dapat memperjelas dalam penyajian materi dan informasi sehingga proses belajar lebih efektif dan dapat meningkatkan hasil belajar, perhatian peserta didik dalam belajar lebih terarah sehingga dapat meningkatkan motivasi belajar, mengatasi keterbatasan indera, ruang, dan waktu. Selain itu media pembelajaran juga dapat menyetarakan pengalaman kepada setiap peserta didik tentang peristiwa di lingkungan mereka.

\subsection{Teknologi dalam Pembelajaran}

Penggunaan media pembelajaran berbasis Teknologi Informasi (TI) kini menjadi sebuah kebutuhan dalam proses pembelajaran, namun tidak mudah dalam mengimplementasikannya. Ada beberapa teknik yang harus diperhatikan agar media yang dipilih dapat digunakan dengan maksimal dan sesuai dengan tujuan media. Berdasarkan Kamus Besar Bahasa Indonesia pembelajaran berbasis teknologi informasi dan komunikasi merupakan suatu proses belajar berdasarkan pengetahuan ilmu eksakta untuk memperoleh sebuah informasi, pengiriman dan penerimaan pesan antara dua orang atau lebih sehingga pesan yang disampaikan lebih mudah untuk dipahami. Pemanfaatan teknologi dalam pembelajaran adalah sebuah upaya mengorganisasi lingkungan untuk membangun kondisi belajar berdasarkan teknologi informasi dan komunikasi untuk peserta didik yang didalamnya terdapat sumber bahan belajar, alat bantu belajar, suasana belajar, dan meningkatkan motivasi belajar [5]. Setiap proses pembelajaran tentunya memiliki manfaat dan memberikan hasil yang diharapkan bagi semua pihak yang terlibat didalamnya. Untuk menciptakan pembelajaran berbasis teknologi informasi dan komunikasi yang efektif ada beberapa prinsip yang harus diperhatikan seperti motivasi, perhatian mahasiswa, aktivitas pembelajaran, umpan balik, dan perbedaan individu.

\subsection{Tipografi}

Menurut Danton Sihombing, Tipografi adalah ilmu yang mempelajari segala sesuatu berkaitan dengan huruf [6]. Seperti halnya musik, tipografi merupakan konsep yang abstrak. Seseorang dapat mengenali karakteristik, kesan, dan suasana hati, seperti perasaan gembira, sedih, optimisme, ataupun romantic dengan mendengan sebuah lagu. Peran tipografi sangat penting dalam menentukan keberhasilan suatu bentuk komunikasi visual [6]. Yang mana sebagai alat berkomunikasi tipografi harus dapat menyampaikan pesan dalam bentuk yang jelas dan mudah terbaca. Keberhasilan desain tipografi dalam penyampaian pesan dipengaruhi oleh beberpa prinsip tipografi, diantaranya : 
1. Legibility : Tingkat keterbacaan huruf berdasarkan kualitasnya, yaitu bagaimana sebuah huruf dapat dibedakan dengan huruf yang lain. Dalam sebuah proses desain tentunya dapat dilakukan penyusunan huruf dengan cropping ataupun overlapping yang dapat mengurangi tingkat keterbacaan sebuah huruf. Untuk mengantisipasi hal tersebut maka karakteristik bentuk tiap huruf harus dikenali dengan baik.

2. Readibility : Ukuran seberapa mudah sebuah huruf dapat dibaca dengan memperhatikan hubungan antara huruf satu dangan huruf lain. Karena jarak antar huruf tidak dapat diukur secara matematis, maka harus dilihat dan dirasakan. Penggunaan spasi yang tidak tepat dapat mengurangi tingkat keterbacaan sebuah huruf.

3. Visibility : Ukuran seberapa besar kemampuan sebuah kata atau kalimat dapat terbaca pada jarak tertentu.

4. Clarity : Ukuran seberapa besar sebuah kata atau kalimat dapat menyampaikan informasi dengan jelas dan mudah dimengerti oleh pembaca. Beberapa unsur yang mempengaruhi clarity adalah visual hierarchy, pemilihan huruf dan penggunaan warna.

Sebagai salah satu bagian dalam desain, tipografi sangat erat kaitannya dengan bidang keilmuan lain seperti bidang komunikasi, bidang teknologi, bidang psikologi dan lainnya [7].

\subsection{Audio Visual}

Media audio visual merupakan suatu media yang digunakan untuk menyampaikan informasi dengan menggunakan karakteristik audio (suara) dan visual (gambar). Media audio visual mempunyai kemampuan yang optimal untuk menyampaikan sebuah informasi karena didalamnya mengandung unsur suara dan gambar. Terdapat dua jenis media audio visual, diantaranya adalah a) audio visual diam adalah jenis media yang menampilan suara dan gambar diam. Contohnya film bingkai suara (sound slide), dan cetak suara. b) audio visual gerak adalah sebuah media yang menampilkan unsur suara dan gambar yang bergerak contohnya video. Menurut riset yang telah dilakukan Media audio visual mempunyai tingkat efektivitas yang cukup tinggi yaitu rata-rata diatas $60 \%$ sampai $80 \%$ [4].

\subsection{Model ADDIE}

Pendekatan ADDIE adalah model desain pembelajaran yang bedasarkan pada pendekatan sistem yang efektif dan efisien. Proses pada pendekatan model ini bersifat interaktif yakni hasil evaluasi setiap fase dapat membawa pengembangan pembelajaran ke dalam fase selanjutnya. Model ini terdiri 5 fase atau tahap yaitu 1) Analyze (Analisis), 2) Design (Desain), 3) Develop (Pengembangan), 4) Implement (Implementasi), 5) Evaluate (Evaluasi) [8]. 


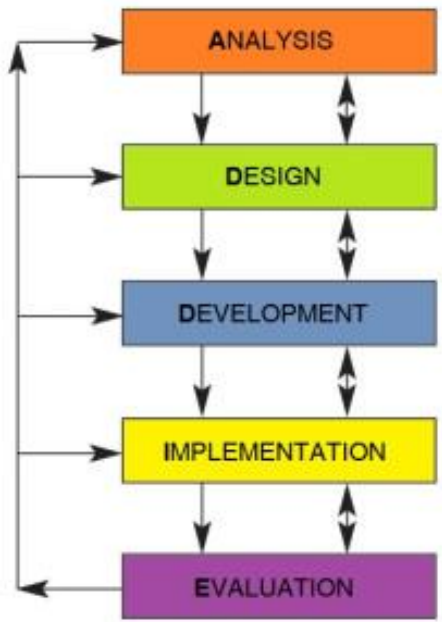

Gambar 1. Tahapan Model Pengembangan ADDIE

[Sumber : Sink, 2014] [8]

Beberapa tahapan dalam model pendekatan ADDIE dijabarkan sebagai berikut:

a. Tahap Analysis (analisis)

Tahap ini merupakan proses melakukan needs assessment (analisis kebutuhan), mengidentifikasi masalah (kebutuhan), dan melakukan analisis tugas (task analysis). Proses analisis digunakan untuk menentukan langkah yang akan dilakukan dalam merancang media pembelajaran. Maka, output yang dihasilkan dari proses analisis yaitu karakteristik profil calon siswa, identifikasi kesenjangan, identifikasi kebutuhan dan analisis tugas yang rinci didasarkan atas kebutuhan.

b. Tahap Design (desain)

Tahap ini melakukan proses pembuatan rancangan atau blue print. Adapun langkah yang dilakukan dalam tahap ini adalah merumuskan tujuan pembelajaran, menyusun dan menyiapkan tes yang didasarkan pada tujuan pembelajaran, dan menentukan strategi pembelajaran yang tepat untuk mencapai tujuan yang telah dirumuskan. Dalam hal ini ada banyak pilihan kombinasi metode dan media yang dapat digunakan dan relevan. Mempertimbangkan sumber-sumber pendukung lain, seperti sumber belajar yang relevan, lingkungan belajar yang seperti apa seharusnya.

c. Tahap Development (pengembangan)

Proses pada tahap ini adalah mewujudkan blue-print atau desain. Proses perwujudan yang dimaksudkan misalnya, dalam tahap desain diperlukan suatu software berupa multimedia pembelajaran, maka software multimedia tersebut harus dikembangkan, atau diperlukan sebuah modul cetak, maka modul tersebut perlu dikembangkan. Begitu pun halnya dengan lingkungan belajar yang akan digunakan untuk mendukung proses pembelajaran semuanya disiapkan dalam tahap development ini. Dalam tahap pengembangan ada satu langkah penting yang perlu dilakukan yaitu sebelum produk diimplementasikan sebelumnya dilakukan uji coba terlebih dahulu. Yang mana uji coba merupakan salah satu proses dalam pendekatan model ADDIE, atau yang disebuat dengan evaluasi. Hasil uji coba yang dilakukan akan digunakan untuk revisi atau memperbaiki sistem pembelajaran yang dikembangkan. 


\section{d. Tahap Implementation (implementasi)}

Tahap implementasi merupakan langkah nyata untuk menerapkan sistem pembelajaran yang dirancang. Artinya, pada tahap implementasi ini semua yang telah dikembangkan disetting sesuai dengan peran atau fungsinya sehingga dapat diimplementasikan. Misalnya, jika memerlukan software tertentu maka software yeng dibutuhkan tersebut harus sudah terinstal. Jika dibutuhkan penataan lingkungan tertentu, maka lingkungan disetting sesuai dengan rancangan. Maka, produk yang dibuat dapat diimplementasikan sesuai skenario atau desain awal.

e. Tahap Evaluation (evaluasi)

Evaluasi adalah tahap untuk mengetahui sistem pembelajaran yang dirancang sesuai dengan tujuan atau tidak. Proses evaluasi dapat terjadi pada ke-empat tahap yang disebut dengan evaluasi formatif, tujuan dari evaluasi formatif adalah untuk kebutuhan revisi. Seperti pada tahap rancangan, diperlukan evaluasi formatif misalnya review ahli untuk memberikan masukan pada rancangan yang sedang dibangun. Pada tahap pengembangan, mungkin perlu dilakukan uji coba dari produk yang dikembangkan atau mungkin perlu evaluasi kelompok kecil. [9]

\section{METODE PENELITIAN DAN PEMBAHASAN}

\subsection{Metode Penelitian}

a. Lokasi dan Waktu Penelitian

Penelitian dilakukan pada Program Studi DKV (Desain Komunikasi Visual) Universitas Dian Nuswantoro Semarang pada mata kuliah Tipografi Semester Ganjil Tahun Ajaran 2016/2017.

\section{b. Jenis Penelitian}

Pendekatan yang digunakan dalam penelitian ini adalah pendekatan kualitatif. Menurut Bodgan dan Taylor, Penelitian kualitatif merupakan sebuah prosedur penelitian yang menghasilkan data deskriptif berupa kata-kata yang tertulis ataupun lisan dari nara sumber yang diamati [10]. Tujuan dari pendekatan ini adalah untuk menguraikan makna pada sebuah objek melalui data kualitatif yang kemudian diinterpretasikan dengan sebuah rujukan atau referensi ilmiah tentang fakta yang ada dilapangan. Metode yang digunakan untuk merancang media pembelajaran dalam penelitian ini adalah Research and Development dengan menggunakan model ADDIE (Analysis, Design, Development, Implementation, and Evaluation). Pendekatan ini bertujuan untuk mendeskripsikan dan mengetahui kualitas media pembelajaran yang dikembangkan.

\section{c. Teknik Pengumpulan Data}

Data yang digunakan dalam merancang media pembelajaran ini diperoleh berdasarkan sumber data primer dan sumber data skunder. Yang dimaksud dengan sumber data primer adalah data yang didapatkan dari pihak yang bersangkutan secara langsung, contohnya seperti wawancara. Sedangkan, sumber data skunder adalah data yang diperoleh dari sumber yang sudah dipublikasikan secara umum, seperti surat kabar, buku ataupun karya ilmiah. Teknik pengumpulan data yang digunakan dalam penelitian ini adalah melalui instrument sebagai berikut : 
1. Wawancara,

Proses wawancara dilakukan kepada para pengajar mata kuliah Tipografi di Universitas Dian Nuswantoro dan mahasiswa yang mengambil mata kuliah Tipografi.

2. Studi Pustaka

Untuk mendukung data-data yang lain dilakukan studi kepustakaan untuk mencarai data yang dibutuhkan dalam melengkapi meteri ataupun informasi lain yang dibutuhkan dalam penelitian ini. Data didapatkan dari buku referensi, internet, literatur seperti jurnal, modul, artikel, maupun karya-karya ilmiah lainnya.

3. Angket

Penyebaran angket atau kuesioner dalam penelitian ini digunakan untuk mengetahui atau melihat tanggapan mahasiswa terhadap hasil uji coba media pembelajaran yang dirancang.

4. Dokumentasi

Dokumentasi yang dilakukan adalah kegiatan pembelajan yang digunakan sebagai pendukung untuk keperluan sumber data yang dibutuhkan.

\subsection{Pembahasan}

Penelitian ini memanfaatkan perkembangan teknologi informasi sebagai pendukung media pembelajaran berbasis audio visual untuk mata kuliah Tipografi Program Studi Desain Komunikasi Visual Universitas Dian Nuswantoro. Melalui media audio visual informasi yang disampaikan akan lebih mudah dipahami oleh mahasiswa karena memiliki keunggulan dalam unsur suara dan visual atau gambar dalam penyajiannya. Untuk merancang media pembelajaran ini dilakukan dengan model ADDIE yang memiliki lima tahap yaitu Analysis, Design, Development, Implementation dan Evaluation. Langkah yang dilakukan dalam penelitian ini adalah sebagai berikut :

1. Analysis

Langkah pertama yang dilakukan dalam penelitian ini adalah mengumpulkan informasi dengan melakukan wawancara kepada pengajar mata kuliah Tipografi di Universitas Dian Nuswantoro. Pertanyaan yang diajukan adalah untuk menggali permasalahan atau kendala dalam pengajaran mata kuliah Tipografi, solusi yang diusulkan sebagai pemecahan permasalahan tersebut dan pengembangan konten materi yang akan disampaikan. Selain itu juga dilakukan wawancara kepada mahasiswa yang mengambil mata kuliah Tipografi. Tahap analisis ini dilakukan dengan tujuan untuk mendapatkan data pendukung dalam merancang media pembelajaran. Adapun hasil dari wawancara yang dilakukan diketahui bahwa terdapat dilematisasi para pengajar dalam mengoptimalkan proses pembelajaran untuk mencapai tujuan yang diharapkan. Penggunaan beberapa media pembelajaran telah diupayakan, seperti menggunakan slide power point. Meskipun begitu, kerapkali dalam tahap evaluasi proses pembelajaran muncul ketidak puasan para pengajar dengan hasil yang kurang maksimal karena mahasiswa tidak dapat memahami materi secara utuh, sehingga pengaplikasian materi kedalam prakteknya sering tidak sesuai. Kurangnya media teknologi komunikasi yang menarik dalam penyampaian materi membuat mahasiswa cepat jenuh, selain itu ketika mahasiswa belajar mandiri untuk mengulang materi yang telah disampaikanpun mengalami 
kesulitan karena tidak terdapat detail penjelasan seperti ketika dijelaskan dalam pembelajaran dikelas.

Oleh sebab itu dibutuhkan media pembelajaran berbasis teknologi yang menarik yang dapat meningkatkan motivasi belajar mahasiswa dan menjadikan proses pembelajaran menjadi lebih efektif. Media yang dipilih sebagai media pembelajaran dalam penelitian ini adalah audio visual. Dipilihnya media audio visual untuk mengembangkan media pembelajaran dalam mata kuliah tipografi karena melalui media ini dirasa informasi yang disampaikan akan lebih mudah dipahami oleh mahasiswa karena memiliki keunggulan dalam unsur suara dan visual atau gambar dalam penyajiannya. Dari data tersebut sebelum merancang media yang diusulkan maka dilakukan perumusan pengembangan materi dengan mengidentifikasi kompetensi dasar mata kuliah tipografi. Materi dikembangkan sesuai dengan Silabus dan didukung dengan studi literature dari buku karangan Danton sihombing yang berjudul Tipografi Dalam Desain Grafis dan Buku karangan Surianto Rustan dengan judul Huruf, Font dan Tipografi.

\section{Design}

Pada tahap ini proses yang dilakukan adalah merumuskan tujuan pembelajaran dan menyusun perencanaan kebutuhan dalam menyusun media pembelajaran. Proses ini diawali dengan menyusun materi berdasarkan garis besar data yang didapatkan dari hasil analisisagar materi yang disampaikan lebih singkat dan padat. Materi disusun berdasarkan silabus yang ditunjang dengan pengembangan dari berbagai literatur. Salah satu topik materi yang akan diuji cobakan dalam media pembelajaran yang dibuat adalah materi penerapan tipografi pada logotype. Kompetensi Akhir yang diharapkan setelah mahasiswa mempelajari topik ini mahasiswa dapat menciptakan logotype yang dibuat secara manual sesuai dengan teori penerapan tipografi pada logotype. Materi yang telah disusun dirumuskan kembali dalam sebuah naskah storyboard untuk direalisasikan kedalam media pembelajaran berbasis audio visual. Selanjutnya melakukan identifikasi perancanaan kebutuhan-kebutuhan lain yang diperlukan untuk merancang media pembelajaran dengan audio visual. Hal yang disiapkan seperti lokasi, property untuk pengambilan video, perangkat lunak dan hardware yang digunakan. Adapun software yang digunakan dalam merancang media pembelajaran audio visual ini adalah Adobe Photosop, Adobe Premiere, Adobe After Effect dan fruity Loop 12. Keseluruhan software tersebut dilakukan instalasi pada PC yang akan digunakan sebagai pengolahan gambar, video maupun audio.

\section{Development}

Tahap Development merupakan tahap mewujudkan rancangan ke dalam media pembelajaran yang berisi teks, suara, gambar maupun animasi, media tersebuat adalah media audio visual. Dalam merancang media tersebut terlebih dahulu dilakukan tahap pengambilan video atau shooting yang dilakukan di Laboratorium fotografi Universitas Dian Nuswantoro. Selain take video juga lakukan tahap dubbing suara, dengan tujuan untuk mendapatkan suara yang lebih jelas dan jernih. 
Sebelum file video dan audio digabungkan dibutuhkan proses pengolahan grafik untuk menambahkan unsur grafik atau gambar dalam media pembelajaran agar lebih menarik. Pengolahan gambar dilakukan dengan software adobe photosop. Elemen yang dibuat diantaranya adalah pengolahan background, dan gambargambar pendukung yang ditampilkan dalam media pembelajaran. Selain elemen grafik, audio juga salah satu elemen yang tidak kalah penting dalam pembuatan media pembelajaran ini. Audio diolah dengan menggunakan software fruity loop 12. Software tersebuat adalah sebuah aplikasi pada komputer yang digunakan untuk proses merekam, mengolah dan membuat audio. Proses audio dilakukan untuk mengolah suara menjadi backsound dan menghilangkan suara-suara yang noise dari hasil dubbing.

Setelah semua elemen yang dibutuhkan selesai, maka dilakukan tahap menyatukan video, gambar dan audio. Pengolahan video dilakukan dengan software adobe premiere untuk menyatukan seluruh file pendukung. Software Adobe after effect juga digunakan untuk menambahakan beberapa efek dalam video dan menambahkan elemen teks animasi untuk membuat media pembelajaran menjadi lebih menarik. Tahap terakhir adalah rendering project dengan format MP4 agar mudah dalam mengimplementasikan.

Namun, sebelum media pembelajaran diimplementasikan terlebih dahulu dilakukan validasi untuk untuk menguji, memberikan penilaian dan saran terhadap media pembelajaran tersebuat. Validasi Ahli materi dilakukan dengan melibatkan beberapa pengampu mata kuliah tipografi dan validasi ahli Media dengan melibatkan beberapa dosen pengampu mata kuliah Audio Visual DKV UDINUS. Hasil evalusasi yang dilakukan oleh tim validasi ahli materi dan media digunakan untuk menyempurnakan media pembelajaran.

\section{Implementation}

Media pembelajaran ini diimplementasikan dalam sistem pembelajaran kelas. Media pembelajaran berupa audio visual diserahkan kepada para pengajar mata kuliah Tipografi untuk diuji cobakan kepada mahasiswa. Produk media pembelajaran audio visual dikemas dalam bentuk file MP4 untuk ditayangkan dikelas lewat media proyektor LCD.

\section{Evaluation}

Tahap evaluasi pada penelitian ini bertujuan untuk mendapatkan tanggapan atau respon dari responden. Adapun informasi yang digali dari proses evaluasi ini adalah berkaitan dengan apakah media pembelajaran yang dirancang sebagai penunjang kegiatan pembelajaran mata kuliah Tipografi sesuai dengan tujuan yang diharapkan. Data yang diperoleh dari hasil evaluasi dapat digunakan untuk menyempurnakan media pembelajaran tersebut. Evaluasi dilakukan dengan menggunakan angket. Responden pada penelitian ini adalah para mahasiswa yang mengambil mata kuliah Tipografi semester ganjil 2016/2017 jurusan desain komunikasi visual dengan jumlah 40 orang. Adapun hal-hal yang dinilai adalah relevansi materi dan efektivitas 
dari media pembelajaran yang telah dirancang. Hasil evalusi oleh mahasiswa adalah sebagai berikut :

Tabel 1. Pengelompokkan kategori kualitas berdasarkan persentase [Sumber : Suharsimi Arikunto, 2012] [11]

\begin{tabular}{|c|c|}
\hline Presentase & Kategori \\
\hline $80 \%-100 \%$ & Sangat Tinggi \\
\hline $60 \%-79 \%$ & Tinggi \\
\hline $40 \%-59 \%$ & Cukup \\
\hline $20 \%-39 \%$ & Rendah \\
\hline Kurang dari $20 \%$ & Sangat Rendah \\
\hline
\end{tabular}

Tabel 2. Hasil evaluasi media pembelajaran berdasarkan angket [Sumber: Puri, Dwi, \& Dimas, 2016]

\begin{tabular}{|c|l|l|}
\hline No. & \multicolumn{1}{|c|}{ Aspek } & \multicolumn{1}{c|}{ Hasil } \\
\hline 1. & Kejelasan Materi & $80 \%$ menilai sangat jelas \\
\hline 2. & Komunikasi Visual & $74 \%$ menilai menarik \\
\hline 3. & Manfaat & $88 \%$ menilai sangat bermanfaat \\
\hline
\end{tabular}

Hasil dari tabel di atas dapat diketahui bahwa hasil evaluasi yang dilakukan dari 40 mahasiswa sebagai responden yang diuji cobakan, hasil yang diperoleh dari aspek kejelasan materi dalam media pembelajaran $80 \%$ mahasiswa menganggap materi yang disampaikan dalam media pembelajaran audio visual sangat jelas. sedangkan aspek komunikasi visual berdasarkan huruf, warna yang digunakan, layout, kualitas gambar dan video $74 \%$ mahasiswa menilai menarik. Aspek kemanfaatan $88 \%$ mahasiswa menilai media pembelajaran sangat bermanfaat. Sehingga dari ketiga aspek tersebut dapat disimpulkan media pembelajaran berbasis audio visual yang diterapkan pada mata kuliah Tipografi sangat mendukung media pembelajaran. 
Bentuk akhir media pembelajaran berbasis audio visual untuk mata kuliah Tipografi :

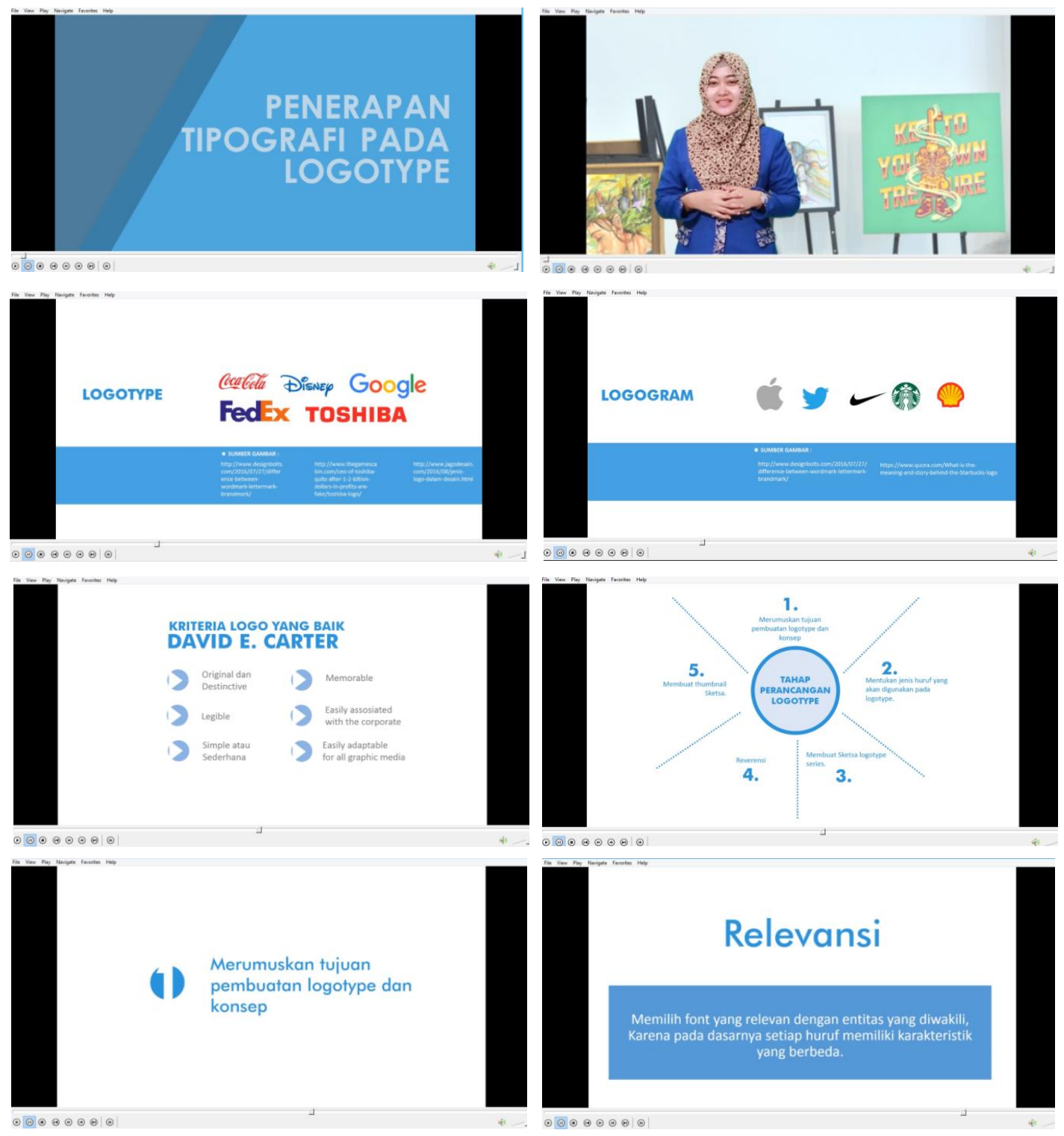

Gambar 2. Preview media pembelajaran berbasis audio visual mata kuliah Tipografi [Sumber: Puri, Dwi, \& Dimas, 2016]

\section{KESIMPULAN}

\subsection{Kesimpulan}

Proses yang dilakukan dalam penelitian ini yaitu merancang media pembelajaran dengan memanfaatkan teknologi informasi dalam mata kuliah Tipografi pada Program Studi DKV Universitas Dian Nuswantoro. Perkembangan teknologi informasi kini banyak memberikan dampak positif dalam kemajuan bidang pendidikan. Teknologi informasi tidak lagi hanya digunakan untuk menyampaikan sebuah informasi, namun juga dapat digunakan untuk mendukung media dalam proses pembelajaran. Penggunaan teknologi informasi sebagai penunjang dalam media pembelajaran dapat dilakukan dengan berbagi cara, salah satunya adalah dengan menggunakan media 
audio visual. Dipilihnya media audio visual untuk mengembangkan media pembelajaran dalam mata kuliah tipografi karena melalui media ini informasi yang disampaikan akan lebih mudah dipahami oleh mahasiswa karena memiliki keunggulan dalam unsur suara dan visual atau gambar dalam penyajiannya.

Metode ADDIE digunakan untuk mendukung perancangan media pembelajaran pada penelitian ini, sehingga dapat didapatkan kesimpulan sebagai berikut :

1. Pendekatan ADDIE dapat digunakan untuk merancang media audio visual yang berbasil teknologi yang dapat mendukung proses pembelajaran.

2. Hasil evaluasi yang telah dilakukan menunjukkan bahwa media audio visual sebagai media pembelajaran sangat mendukung proses pembelajaran dalam mata kuliah Tipografi pada Program Studi DKV Universitas Dian Nuswantoro.

\subsection{Saran}

Berdasarkan kesimpulan yang telah terpapar, saran yang diberikan dari penelitian ini adalah:

1. Media pembelajaran berbasis audio visual pada mata kuliah Tipografi ini dapat dikembangkan dan diterapkan untuk kegiatan pembelajaran pada mata kuliah yang lain.

2. Untuk pengembangan selanjutnya media pembelajaran audio visual ini dapat diterapkan dalam media e-learning.

\section{DAFTAR PUSTAKA}

[1] Nini Subini, dkk. 2012. Psikologi Pembelajaran.Yogyakarta : Mentari Pustaka

[2] Kusrianto, Adi. 2004. Tipografi Komputer untuk Desainer Grafis,Yogyakarta: ANDI

[3] Haryoko S. 2009. Efektivitas Pemanfaatan Media Audio Visual sebagai Alternatif Optimalisasi Model Pembelajaran. Jurnal edukasi 5 (1) : 1-10.

[4] Arsyad, A. 2009. Media Pembelajaran. Jakarta: Raja Grafindo Persada.

[5] Aqib, Zainal. 2002. Profesionalisme Guru dalam pembelajaran, Surabaya: Insan Cendekia.

[6] Sihombing, Danton. 2001. Tipografi Dalam Desain Grafis. Jakarta: Gramedia.

[7] Rustan, Surianto., 2010. Huruf Font Tipografi, Jakarta: P.T Gramedia Pustaka Utama.

[8] Sink, Darryl L. 2014. Design Models and Learning Theories for Adults. American Society for Training and Development.

[9] Chaeruman. 2008. Mengembangkan Sistem Pembelajaran dengan Model ADDIE. Jakarta: PT. Remaja Rosdakarya.

[10] Moleong, L. J. 2005. Metode Penelitian Kualitatif. Bandung: PT. Rosdakarya

[11] Suharsimi, Arikunto. 2012. Dasar-dasar Evaluasi Pendidikan edisi 2. Jakarta: Bumi Aksara. 